BAREKENG: Jurnal Ilmu Matematika dan Terapan

March 2021

Vol. 15 No. 1

Page 029-036

P-ISSN: 1978-7227 E-ISSN: 2615-3017

\title{
PERBEDAAN HASIL BELAJAR SISWA KELAS VIII SMP MENGGUNAKAN MODEL PROBLEM BASED LEARNING (PBL) BERBANTUAN APLIKASI SWISHMAX DAN MODEL PEMBELAJARAN KONVENSIONAL
}

\section{Differences of Students Learning Outcomes at Class VIII SMP Using Problem Based Learning (PBL) Model Assisted With Swishmax Application and Conventional Learning Models}

\author{
Christina M. Laamena ${ }^{1 *}$, W. Mataheru ${ }^{2}$, Febrilia F. Hukom ${ }^{3}$ \\ 1,2,3 Prodi Pendidikan Matematika, FKIP Universitas Pattimura \\ Jl. Ir M. Putuhena Ambon, 97233, Maluku, Indonesia \\ Corresponding author e-mail: ${ }^{1 *}$ christinmath18@gmail.com
}

\begin{abstract}
Abstrak
Penggunaan.model pembelajaran yang tepat dapat memberikan hasil belajar matematika yang lebih baik. Khusus untuk materi geometri, aplikasi swishmax dapat membantu guru memvisualkan gambar sehingga siswa dapat memahami apa yang disampaikan. Penelitian ini bertujuan untuk mengetahui perbedaan hasil belajar siswa yang diajarkan dengan menggunakan model Problem Based Learning (PBL) berbantuan aplikasi Swishmax dan model pembelajaran konvensional pada materi prisma dan limas. Penelitian ini adalah penelitian eksperimen dengan populasi siswa kelas VIII SMP yang terdiri dari 7 kelas dan sampel 2 kelas yang dipilih menggunakan teknik Purposive Sampling. Instrumen yang digunakan berbentuk tes yang terdiri atas tiga soal uraian. Teknik analisis data yang digunakan adalah analisis deskriptif dan statistik uji-t. Uji hipotesis menggunakan uji beda rata-rata atau uji-t mengasilkan nilai sig (2-tailed) $<\alpha$ artinya terdapat perbedaan hasil belajar siswa kelas VIII SMP menggunakan model Problem Based Learning (PBL) berbantuan aplikasi Swishmax dan model pembelajaran konvensional pada materi prisma dan limas.
\end{abstract}

Kata Kunci : Problem Based Learning (PBL), Swishmax, Prisma, dan Limas

Abstract

The use of the right learning model can provide better mathematics learning outcomes. Especially for geometry material, the Swishmax application can help teachers visualize images so that students can understand what is being conveyed. This study aims to determine the differences in student learning outcomes taught using the Problem Based Learning (PBL) model assisted by the Swishmax application and conventional learning models on the prism and pyramid material. This research is an experimental study with a population of class VIII junior high school students consisting of 7 classes and a sample of 2 classes selected using purposive sampling technique. The instrument used was in the form of a test consisting of three description questions. The data analysis technique used is descriptive analysis and t-test statistics. Hypothesis testing using the average difference test or t-test yields sig $(2$-tailed) $<\alpha$, which means that there are differences in learning outcomes for VIII grade students using the Problem Based Learning (PBL) model assisted by the Swishmax application and conventional learning models on prism and pyramid

Keywords: Problem Based Learning (PBL), Swishmax, Prism, and Pyramid

Article info:

Submitted: $13^{\text {th }}$ August 2020

Accepted: $24^{\text {th }}$ February 2021

How to cite this article:

Ch. M. Laamena, W. Mataheru, F. F. Hukom, "PERBEDAAN HASIL BELAJAR SISWA KELAS VIII SMP MENGGUNAKAN MODEL PROBLEM BASED LEARNING (PBL) BERBANTUAN APLIKASI SWISHMAX DAN MODEL PEMBELAJARAN KONVENSIONAL", BAREKENG: J. Il. Mat. \& Ter., vol. 15, no. 1, pp. 029-036, Mar 2021.

\section{(i) (2)}

This work is licensed under a Creative Commons Attribution-ShareAlike 4.0 International License.

Copyright (C) 2021 Christina M. Laamena, W. Mataheru, Febrilia F. Hukom 


\section{PENDAHULUAN}

Matematika adalah ilmu pengetahuan yang berperan penting dalam perkembangan teknologi. Hal ini sesuai dengan pendapat Kamta (Makalaipessy [1]) bahwa matematika merupakan ilmu dasar yang menjadi tolak ukur bagi perkembangan dan kemajuan teknologi dan bukan pelajaran yang sulit karena matematika bisa menjadi pelajaran yang sangat mudah, menarik, dan merangsang kreativitas siswa. Matematika memberikan keterampilan bagi seseorang untuk dapat berpikir secara logis dan sistematis dalam menyelesaikan masalah. Pentingnya matematika tak lantas menjadikan matematika sebagai mata pelajaran yang disenangi, sebaliknya matematika menjadi mata pelajaran yang dianggap sulit dan tidak disenangi oleh banyak siswa, karena dalam proses pembelajaran matematika yang terjadi di kelas terkesan membosankan. Hal ini mengakibatkan hasil belajar siswa rendah.

Rendahnya hasil belajar matematika siswa juga disebabkan oleh proses pembelajaran yang cenderung terpusat pada guru. Ratumanan dan Laurens [2] menemukan beberapa faktor penyebab terkait pembelajaran, antara lain: (1) guru matematika umumnya menggunakan pendekatan mekanistik dan mengabaikan aspek kontekstual, sehingga pembelajaran matematika menjadi tidak menarik dan kurang memotivasi siswa, dan (2) proses pembelajaran umumnya didominasi oleh ceramah dan sedikit latihan. Guru terlalu terpaku pada buku teks, konsep diajarkan sesuai dengan alur yang terdapat pada buku teks, bahkan contoh-contoh yang diberikan juga mengacu pada contoh yang tertulis pada buku teks. Kemampuan guru untuk mengembangkan materi pembelajaran masih terbatas, kegiatan-kegiatan pengayaan juga relatif terbatas.

Dalam kaitannya dengan prisma dan limas sebagai salah satu bagian dari materi matematika sekolah, ditemukan beberapa kesalahan siswa dalam memahami materi tersebut. Hal ini tercermin dari beberapa hasil penelitian, di antaranya: (1) Syarir, dkk [3] menemukan bahwa siswa tidak memahami konsep dasar sehingga kesulitan dalam memahami dan menggunakan prinsip, (2) Novitasari [4] menemukan bahwa siswa melakukan kesalahan dalam mencari volume prisma dan tinggi limas, (3) Sumadiasa [5] juga menemukan bahwa siswa menganggap tinggi limas sebagai tinggi sisi tegak dan rusuk tegak limas, dan (4) Istiani \& Hidayatulloh [6] menemukan bahwa kesalahan siswa dalam menerapkan rumus, hal ini terjadi karena siswa tidak teliti dan tidak dapat memahami maksud soal. Siswa juga melakukan kesalahan dalam menentukan bentuk bangun yang diminta.

Sehubungan dengan permasalahan tersebut, maka diperlukan model pembelajaran yang dapat mengembangkan kemampuan siswa dalam pemecahan masalah sehingga pembelajaran menjadi bermakna. Salah satu model pembelajaran yang dapat digunakan adalah model Problem Based Learning (PBL). Kelebihan PBL menurut Saefuddin \& Berdiati [7] yaitu dengan PBL akan terjadi pembelajaran bermakna. Belajar dapat semakin bermakna dan dapat diperluas ketika siswa berhadapan dengan situasi dimana konsep diterapkan.

Model Problem Based Learning (PBL) dapat mengatasi kesulitan belajar siswa dalam memahami materi bangun ruang khususnya prisma dan limas. Penelitian yang dilakukan Azizah, dkk Rodhi dan Khotimah [8] [9], [10], [8] menyimpulkan bahwa pembelajaran dengan menggunakan model Problem Based Learning (PBL) mampu meningkatkan keaktifan siswa dan kemampuan dalam memecahkan masalah matematika, sehingga dapat meningkatkan hasil belajar matematika yang lebih baik jika dibandingkan dengan pembelajaran yang menggunakan model pembelajaran langsung. Penerapan model Problem Based Learning (PBL) selain memiliki kelebihan, juga memiliki kekurangan. Menurut Ambarjaya [11] kekurangan Problem Based Learning (PBL) yaitu ketika siswa tidak memiliki minat atau tidak mempunyai kepercayaan bahwa masalah yang dipelajari sulit untuk dipecahkan, maka mereka akan merasa enggan untuk mencoba. Untuk mengantisipasi hal tersebut, diperlukan media pembelajaran sehingga pembelajaran menjadi menyenangkan. Salah satu media pembelajaran yang dapat digunakan adalah aplikasi Swishmax.

Swishmax menurut Pakaya [12] merupakan software atau aplikasi presentasi yang memiliki kemampuan untuk membuat animasi yang kompleks dalam waktu yang cepat. Animasi yang dihasilkan oleh Swishmax dapat digunakan untuk menarik perhatian siswa dan memotivasi siswa untuk belajar karena adanya pergerakan dan suara untuk mempermudah penggambaran dari suatu materi, dengan Swishmax siswa lebih mudah memahami materi bangun ruang khususnya prisma dan limas yang bersifat abstrak menjadi konkrit. Oleh karena itu, penelitian ini bertujuan untuk mengetahui perbedaan hasil belajar siswa kelas VIII SMP menggunakan model Problem Based Learning (PBL) berbantuan aplikasi Swishmax dan model pembelajaran konvensional pada materi prisma dan limas. 


\section{METODE PENELITIAN}

Penelitian ini merupakan penelitian eksperimen (Experimental Research), dengan desain penelitian Posttest Only Control Group Design [13]. Dalam desain ini terdapat dua kelompok yaitu kelompok yang diberi perlakuan disebut kelompok eksperimen dan kelompok yang tidak diberi perlakuan disebut kelompok kontrol. Adapun desain penelitian ini sebagai berikut.

Tabel 1. Desain Penelitian Posttest Only Control Group Design

\begin{tabular}{llc}
\hline Kelompok & Perlakuan & Tes Akhir \\
\cline { 1 - 1 } Eksperimen & $\mathrm{T}$ & $\mathrm{P}$ \\
\cline { 1 - 2 } Kontrol & - & \\
\hline
\end{tabular}

Keterangan:

$\mathrm{T}$ : perlakuan dengan model Problem Based Learning (PBL) berbantuan aplikasi Swishmax

$\mathrm{P}$ : tes akhir (Posttest) untuk kelas eksperimen dan kelas control

Populasi dalam penelitian ini adalah seluruh siswa kelas VIII SMP Negeri 13 Ambon yang terdiri dari 7 kelas. Dalam pengambilan sampel, peneliti menggunakan teknik Purposive Sampling. Purposive Sampilng adalah teknik penentuan sampel dengan pertimbangan tertentu [14].

Dalam penelitian ini, tes tertulis digunakan sebagai teknik pengumpulan data. Tes ini dilakukan setelah pembelajaran materi prisma dan limas. Data hasil penelitian yang diperoleh akan dianalisis dengan menggunakan analisis deskriptif dan statistik uji-t. Analisis deskriptif digunakan untuk mendeskripsikan hasil belajar siswa pada kelas eksperimen dan kelas kontrol, sedangkan statistik uji-t dilakukan untuk melihat perbedaan hasil belajar antara kelas eksperimen dan kelas kontrol. Sebelum melakukan pengujian hipotesis dengan uji-t, terlebih dahulu dilakukan uji prasyarat analisis dengan menggunakan uji normalitas dan uji homogenitas terhadap data hasil tes akhir siswa.

\section{HASIL DAN PEMBAHASAN}

\subsection{Hasil}

Hasil perhitungan analisis data dalam penelitian ini menggunakan software Statistical Product Service Solution (SPSS) versi 24.0. Sampel dalam penelitian ini dipilih dengan mempertimbangkan nilai rata-rata yang relatif sama. Berdasarkan nilai rata-rata dari 7 kelas, maka peneliti memilih kelas $\mathrm{VIII}_{3}$ dengan nilai 78.22 sebagai kelas eksperimen yang akan diajarkan dengan model Problem Based Learning (PBL) berbantuan aplikasi Swishmax dan kelas VIII $_{4}$ dengan nilai 78.23 sebagai kelas kontrol yang akan diajarkan dengan model pembelajaran konvensional. Pada kelas eksperimen siswa diberikan BA (Bahan Ajar) dan LAS (Lembar Aktivitas Siswa), sedangkan pada kelas kontrol guru memberikan materi pelajaran sesuai dengan fase-fase pembelajaran pada model pembelajaran konvensional.

Setelah proses pembelajaran pada kelas eksperimen dan kelas kontrol dilakukan dan tes hasil belajar siswa didapat, selanjutnya dilakukan perhitungan analisis data dan diperoleh nilai rata-rata hasil belajar siswa pada kelas eksperimen dan kelas kontrol, sebagai berikut.

Tabel 2. Nilai Rata-rata Hasil Belajar Siswa

\begin{tabular}{cc}
\hline Kelas & Nilai Rata-rata \\
\hline Eksperimen & 37.86 \\
\hline Kontrol & 21.84 \\
\hline
\end{tabular}

Berdasarkan tabel di atas, hasil belajar siswa pada kelas eksperimen lebih baik dibandingkan kelas kontrol. Adapun rincian hasil tes pada masing- masing kelas, sebagai berikut: 
Tabel 3. Hasil Belajar Siswa

\begin{tabular}{cccc}
\hline \multirow{2}{*}{ Kualifikasi } & Nilai & \multicolumn{2}{c}{ Jumlah Siswa } \\
\cline { 3 - 4 } & & $\begin{array}{c}\text { Kelas } \\
\text { Eksperimen }\end{array}$ & Kelas Kontrol \\
\hline Sangat Tinggi & $85 \% \leq x$ & 1 & $\mathbf{0}$ \\
\hline Tinggi & $70 \% \leq x<85 \%$ & 0 & 0 \\
\hline Sedang & $55 \% \leq x<70 \%$ & 12 & 5 \\
\hline Rendah & $40 \% \leq x<55 \%$ & 11 & 18 \\
\hline Sangat Rendah & $x<40 \%$ &
\end{tabular}

Berdasarkan Tabel 3 di atas, terlihat bahwa tidak ada siswa yang memperoleh kualifikasi sangat tinggi pada kedua kelas, untuk kualifikasi tinggi jumlah siswa pada kelas eksperimen dan kelas kontrol sama yaitu 1 siswa (4.17\%), untuk kualifikasi sedang pada kedua tidak ada, untuk kualifikasi rendah pada kelas eksperimen berjumlah 12 siswa (50\%) dan pada kelas kontrol berjumlah 5 siswa (20,83\%), sedangkan untuk kualifikasi sangat rendah pada kelas eksperimen berjumlah 11 siswa $(45,83 \%)$ dan pada kelas kontrol berjumlah 18 siswa (75\%). Berikut ini perbandingan hasil belajar siswa pada kelas eksperimen dan kelas kontrol.

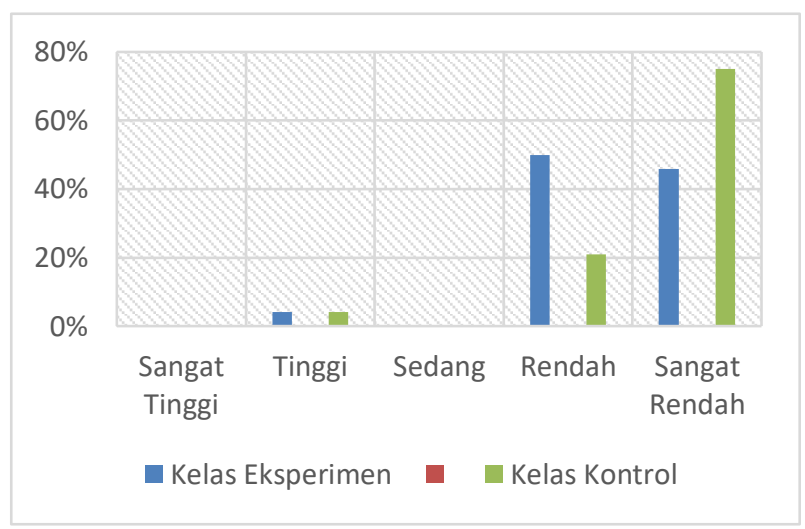

Gambar 1. Perbandingan Hasil Belajar

Berdasarkan Gambar 1 di atas, hasil belajar siswa pada kelas eksperimen lebih baik bila dibandingkan dengan kelas kontrol. Hal ini dikarenakan jumlah siswa yang mendapat kualifikasi sangat rendah pada kelas eksperimen lebih sedikit dibandingkan dengan kelas kontrol.

Setelah diperoleh hasil belajar pada kedua kelas, selanjutnya dilakukan uji prasyarat analisis yang terdiri dari uji normalitas dan uji homogenitas serta pengujian hipotesis dengan menggunakan uji beda ratarata atau uji-t. Uji normalitas dilakukan dengan menggunakan uji Chi-Square dan diperoleh hasil sebagai berikut.

Tabel 4. Hasil Uji Normalitas

\begin{tabular}{ccc}
\hline Kelas & Sig & $\boldsymbol{\alpha}$ \\
\hline Eksperimen & 0.999 & 0.05 \\
\hline Kontrol & 0.998 & \\
\hline \multicolumn{3}{c}{ (Diambil dari output SPSS 24.0) }
\end{tabular}

Berdasarkan Tabel 4, di atas, nilai Sig pada kelas eksperimen dan kelas kontrol yaitu 0.999 dan 0.998 lebih besar dari $\alpha=0.05$. Sesuai dengan ketentuan suatu data berdistribusi normal apabila nilai Sig lebih besar dari taraf signifikan. Hal ini berarti bahwa $\mathrm{H}_{0}$ diterima dan $\mathrm{H}_{1}$ ditolak. Dengan demikian dapat disimpulkan bahwa data pada kedua kelas sampel yang diteliti berdistribusi normal. Setelah kedua kelas sampel yang 
diteliti berdistribusi normal, selanjutnya dilakukan uji homogenitas dengan menggunakan uji $\mathrm{F}$ dan diperoleh hasil sebagai berikut.

Tabel 5. Hasil Uji Homogenitas

\begin{tabular}{ccc}
\hline Kelas & Sig & $\boldsymbol{\alpha}$ \\
\hline Eksperimen & 0.662 & 0.05 \\
\hline Kontrol & & \\
\hline (Diambil dari output SPSS 24.0) &
\end{tabular}

Berdasarkan Tabel 5, nilai Sig pada kelas eksperimen dan kelas kontrol yaitu 0.662 lebih besar dari $\alpha$ $=0.05$. Sesuai dengan ketentuan suatu data dinyatakan homogen apabila nilai Sig lebih besar dari taraf signifikan. $\mathrm{Hal}$ ini berarti bahwa $\mathrm{H}_{0}$ diterima dan $\mathrm{H}_{1}$ ditolak. Dengan demikian dapat disimpulkan bahwa data pada kedua kelas sampel yang diteliti memiliki varians yang homogen. Setelah diketahui melalui uji prasyarat bahwa sampel yang diteliti normal dan homogen, maka selanjutnya pengujian hipotesis dilakukan dengan menggunakan uji beda rata-rata atau uji-t dan diperoleh hasil sebagai berikut.

Tabel 6. Hasil Pengujian Hipotesis dengan Menggunakan Uji-t

\begin{tabular}{ccc}
\hline Kelas & $\begin{array}{c}\text { Sig. } \\
\text { (2-tailed) }\end{array}$ & $\boldsymbol{\alpha}$ \\
\hline Eksperimen & 0.003 & 0.05 \\
\hline Kontrol & & \\
\hline (Diambil dari output SPSS 24.0) &
\end{tabular}

Berdasarkan Tabel 6, nilai Sig. (2-tailed) pada kelas eksperimen dan kelas kontrol yaitu 0.003 lebih kecil dari $\alpha=0.05$. Hal ini berarti bahwa $\mathrm{H}_{0}$ ditolak dan $\mathrm{H}_{1}$ diterima. Dengan demikian dapat disimpulkan bahwa terdapat perbedaan hasil belajar siswa kelas VIII SMP menggunakan model Problem Based Learning (PBL) berbantuan aplikasi Swishmax dan model pembelajaran konvensional pada materi prisma dan limas.

\subsection{Pembahasan}

Berdasarkan hasil perhitungan data pada kedua kelas yang telah diuraikan, diperoleh nilai rata-rata hasil belajar siswa pada kelas eksperimen yang diajarkan dengan model Problem Based Learning (PBL) berbantuan aplikasi Swishmax, yaitu 37.86 dan pada kelas kontrol yang diajarkan dengan model pembelajaran konvensional, yaitu 21.84. Hasil tersebut menunjukkan bahwa model Problem Based Learning (PBL) berbantuan aplikasi Swishmax lebih baik bila dibandingkan dengan model pembelajaran konvensional. Hal ini dikarenakan aktivitas siswa selama poses pembelajaran pada kedua kelas berbeda. Berdasarkan pengamatan peneliti, siswa pada kelas yang diajarkan dengan model Problem Based Learning (PBL) berbantuan aplikasi Swishmax lebih aktif dibandingkan dengan siswa pada kelas yang diajarkan dengan model pembelajaran konvensional.

Pada kelas yang diajarkan dengan model Problem Based Learning (PBL), siswa diberikan perangkat pembelajaran berupa bahan ajar (BA) yang didesain dengan bantuan aplikasi Swishmax, sehingga siswa lebih mudah memahami materi prisma dan limas. Hal ini sesuai dengan penelitian yang dilakukan Basmalah [15] bahwa media pembelajaran yang dikembangkan menggunakan aplikasi Swishmax mampu menampilkan materi pembelajaran dengan animasi grafis yang mudah dipahami. Selain itu, kelebihan lain dari BA tercermin dari penelitian Sari [16] antara lain: (1) bahan ajar yang dikembangkan lebih mempermudah guru dalam memberikan pembelajaran terhadap siswa, dan (2) bahan ajar yang dibuat lebih kreatif dan inovatif sehingga membuat siswa lebih termotivasi dalam pembelajaran matematika dengan materi bangun ruang sisi datar.

Soal-soal yang disajikan dalam lembar aktivitas siswa (LAS) mendorong siswa untuk berpikir kritis sehingga siswa dapat mengembangkan kemampuan penalaran matematika. Handayani \& Mandasari [17] 
menyimpulkan bahwa lembar aktivitas siswa (LAS) berbasis Problem Based Learning (PBL) yang dikembangkan memiliki efek potensial terhadap kemampuan penalaran matematika siswa.

Setting pembelajaran kooperatif dengan menggunakan metode diskusi pada Problem Based Learning (PBL) juga mendorong siswa untuk berkerja sama dalam kelompok agar dapat menyelesaikan LAS yang diberikan guru. Pono \& Lufti [18] menemukan bahwa dengan adanya metode pembelajaran diskusi kelompok dapat meningkatkan motivasi, meningkatkan pemahaman siswa, menumbuhkan rasa kerjasama tim, meningkatkan kemampuan siswa dalam menyelesaikan masalah, memahami materi dan aplikasinya, meningkatkan keaktifan siswa, dan dapat mengeksplor kemampuan siswa untuk berpikir kritis dalam berpendapat.

Model Problem Based Learning (PBL) memberikan kesempatan kepada siswa untuk aktif terlibat dalam proses pembelajaran sehingga siswa dapat membangun pengetahuannya sendiri. Hidayah [19] menyimpulkan bahwa setelah diterapkan pembelajaran matematika menggunakan strategi Problem Based Learning (PBL), guru banyak mengalami perubahan pada proses pembelajaran. Pada proses pembelajaran guru melibatkan siswa untuk lebih aktif dan dapat memperluas wawasan guru mengenai strategi yang digunakan dalam pembelajaran agar proses pembelajaran tidak membosankan dan siswa tidak pasif, sehingga kemampuan pemecahan masalah matematika siswa meningkat.

Pada kelas yang diajarkan dengan model pembelajaran konvensional, guru menjelaskan materi serta memberi contoh pada setiap bagian yang dijelaskan, sementara tugas siswa memperhatikan dan mencatat apa yang disampaikan, serta bertanya jika belum memahami materi. Hal ini sesuai dengan pendapat Djamarah (Palyama [20]) bahwa dalam pembelajaran, model konvensional ditandai dengan ceramah yang diiringi dengan penjelasan, serta pembagian tugas atau latihan. Selama proses pembelajaran berlangsung guru lebih berperan aktif serta mendominasi proses pembelajaran sehingga siswa menjadi pasif. Hal ini dikarenakan dalam proses pembelajaran siswa hanya mendengar penjelasan guru. Aunurrahman [21] mengemukakan bahwa pembelajaran konvensional ditandai dengan guru lebih banyak mengajarkan tentang konsep-konsep bukan kompetensi, tujuannya adalah siswa mengetahui sesuatu bukan mampu melakukan sesuatu dan pada saat proses pembelajaran siswa lebih banyak mendengar.

\section{KESIMPULAN}

Berdasarkan hasil penelitian yang telah dideskripsikan di atas, diperoleh bahwa hasil belajar kelas eksperimen yang diajarkan dengan model PBL berbantuan aplikasi Swishmax lebih tinggi dibandingkan hasil belajar kelas lontrol yang diajarkan dengan model pembelajaran konvensional. Hasil uji beda rata-rata menunjukkan bahwa terdapat perbedaan hasil belajar siswa yang diajarkan menggunakan model Problem Based Learning (PBL) berbantuan aplikasi Swishmax dan model pembelajaran konvensional pada materi prisma dan limas. Hal ini disebabkan oleh perlakuan-perlakuan guru dan aktivitas siswa pada dengan model PBL yang tidak terjadi pada kelas konvensional.

\section{DAFTAR PUSTAKA}

[1] D. Makailipessy, Perbedaan Hasil Belajar Siswa yang Diajarkan dengan Menggunakan Strategi Pembelajaran Everyone is a Teacher Here dan Strategi Pembelajaran Practice Rehearsal Pairs pada Materi Kubus dan Balok di Kelas VIII SMP Negeri 4 Leihitu Barat. Ambon: Program Studi Pendidikan Matematika (Skripsi), 2018.

[2] T. G. Ratumanan and T. Laurens, "Analisis Penguasaan Objek Matematika (Kajian pada Lulusan SMA di Provinsi Maluku)," J. Pendidik. Mat. Raflesia, vol. 1, no. 2, 2016.

[3] dkk Syarir., "Analisis Kesulitan Pemahaman Konsep dan Prinsip Materi Pokok Dimensi Tiga Siswa Kelas XI SMK Keperawatan Yahya Bima," J. Prism. Sains, vol. 1, no. 1, 2013.

[4] V. Novitasari, Analisis Kesalahan Siswa dalam Menyelesaikan Soal-soal pada Materi Bangun Ruang Sisi Datar untuk Siswa Kelas VIII SMP Muhammadiyah 5 Surakarta Tahun Ajaran 2016/2017. Surakarta: Program Studi Pendidikan Matematika Universitas Muhammadiyah (Skripsi)., 2017.

[5] I. . Sumadiasa, "Analisis Kesalahan Siswa Kelas VIII SMP Negeri 5 Dolo dalam Menyelesaikan Soal Luas Permukaan dan Volume Limas," J. Elektron. Pendidik. Mat. Tadulako, vol. 1, no. 2, 2014.

[6] A. Istiani dan Hidayatulloh, "Analisis Kesalahan Siswa dalam Menyelesaikan Soal pada Materi Bangun Ruang Sisi Datar," in Prosiding Seminar Nasional Matematika dan Pendidikan Matematika, 2017. 
[7] H. A. Saefuddin dan I. Berdiati, Pembelajaran Efektif. Bandung: PT Remaja Rosdakarya, 2014.

[8] K. Khotimah, "Penerapan Model Problem Based Learning dengan Pendekatan Kontekstual pada Materi Bangun Ruang Sisi Datar Siswa Kelas VIII," Eduscope J. Pendidikan, Pembelajaran dan Teknol., vol. 3, no. 2, 2018.

[9] F.R. Azizah, dkk, "Penerapan Problem Based Learning pada Materi Luas Permukaan serta Volume Prisma dan Limas Ditinjau dari Kemandirian Belajar Siswa Kelas VIII SMP Negeri 2 Banyudono,” J. Pendidik. Mat. dan Mat., vol. 2, no. 4 , 2018.

[10] Rodhi, "Peningkatan Aktivitas dan Hasil Belajar Materi Bangun Ruang Sisi Datar melalui Model Pembelajaran Problem Based Learning pada Siswa Kelas VIII-D Semester 2 SMP 1 Jekulo Kudus Tahun Pelajaran 2017/2018,” J. Profesi Kegur., vol. 4 , no. 2,2018

[11] S. Ambarjaya, Psikologi Pendidikan dan Pengajaran. Yogyakarta: CAPS, 2012.

[12] N. Pakaya, Pengaruh Media Pembelajaran Animasi Swishmax terhadap Hasil Belajar Siswa pada Materi Atmosfer. Gorontalo: Universitas Negeri Gorontalo (Skripsi), 2014.

[13] Sugiyono, Metode Penelitian Kuantitatif, Kualitatif dan R\&D. Bandung: Alfabeta, 2012.

[14] Sugiyono, Statistika untuk Penelitian. Bandung: Alfabeta. Bandung: Alfabeta, 2015.

[15] Y. N. Basmalah, Pengembangan Media Pembelajaran Matematika Berbasis Multimedia Interaktif Menggunakan Software Swishmax dengan Pendekatan Matematika Realistik pada Pokok Bahasan Luas dan Volume Bangun Ruang Sisi Datar. Yogyakarta: Universitas Islam Negeri Sunan Kalijaga (Skripsi)., 2013.

[16] R. S. P. Sari, Pengembangan Bahan Ajar Matematika pada Materi Bangun Ruang Sisi Datar Menggunakan Software Microsoft Adobe Flash untuk Kelas VIII SMP. Lampung: Program Studi Pendidikan Matematika Universitas Islam Negeri Raden Intan (Skripsi), 2018.

[17] N. Handayani dan Mandasari, "Pengembangan Lembar Kerja Siswa (LKS) Berbasis Problem Based Learning untuk Meningkatkan Kemampuan Penalaran Matematika,” J. Pendidik. Mat. J. Educ., vol. 1, no. 2, 2018.

[18] N. Pono dan M. Lutfi "Pengaruh Pembelajaran Menggunakan Metode Diskusi Kelompok terhadap Prestasi Belajar Siswa pada Pokok Bahasan Geometri Dimensi Tiga di MAN Kalimukti Kec. Pabedilan Kab. Cirebon,” Teaching, J. Eduma Math. Educ. Learn. Teach., vol. 1, no. 2, 2012.

[19] M. Hidayah, "Kemampuan Pemecahan Masalah Siswa Kelas VIII Semester II SMPN 1 Teras Tahun 2014/2015,” 2015.

[20] P. A. M. Palyama, Perbedaan Hasil Belajar Siswa Kelas XI SMA Negeri 7 Ambon yang Diajarkan dengan Menggunakan Model Pembelajaran Kooperatif Tipe Team Assited Individualization (TAI) dan Model Pembelajaran Konvensional pada Materi Turunan. Ambon: Program Studi Pendidikan Matematika Universitas Pattimura (Skripsi)., 2015.

[21] Aunurrahman, Belajar dan Pembelajaran. Bandung: Alfabeta, 2013. 
